\begin{tabular}{|c|c|}
\hline Відомості про автора: & Information about the author: \\
\hline $\begin{array}{l}\text { Гакман Анна Вікторівна - кандидат наук з фізич- } \\
\text { ного виховання і спорту, доцент кафедри теорії та } \\
\text { методики фізичного виховання і спорту, Чернівець- } \\
\text { кий національний університет імені Юрія Федь- } \\
\text { ковича (Чернівці, Україна) }\end{array}$ & $\begin{array}{l}\text { Hakman Anna Viktorivna - Candidate of Scien- } \\
\text { ce (Physical Education and Sport), Associate Pro- } \\
\text { fessor of Theory and Methods of Physical Educa- } \\
\text { tion and Sports, Yuriy Fedkovych Chernivtsi } \\
\text { National University (Chernivtsi, Ukraine) }\end{array}$ \\
\hline \multicolumn{2}{|l|}{$\begin{array}{l}\text { e-mail: an.hakman@chnu.edu.ua } \\
\text { https://orcid.org/0000-0002-7485-0062 }\end{array}$} \\
\hline $\begin{array}{l}\text { Дудіцька Світлана Петрівна - викладач кафедри } \\
\text { теорії та методики фізичного виховання і спорту, } \\
\text { Чернівецький національний університет імені Юрія } \\
\text { Федьковича (Чернівці, Україна) }\end{array}$ & $\begin{array}{l}\text { Dudits'ka Svitlana Petrivna - lecturer at the } \\
\text { Department of Theory and Methods of Physical } \\
\text { Education and Sports, Yuriy Fedkovych Cher- } \\
\text { nivtsi National University (Chernivtsi, Ukraine) }\end{array}$ \\
\hline \multicolumn{2}{|l|}{$\begin{array}{l}\text { e-mail: s.duditska@chnu.edu.ua } \\
\text { https://orcid.org/0000-0001-5015-2465 }\end{array}$} \\
\hline $\begin{array}{l}\text { Вілігорський Олександр Миколайович - старший } \\
\text { викладач кафедри фізичної культури та основ } \\
\text { здоров'я, Чернівецький національний університет } \\
\text { імені Юрія Федьковича (Чернівці, Україна) }\end{array}$ & $\begin{array}{l}\text { Vilihors'kyy Oleksandr Mykolayovych - Senior } \\
\text { Lecturer of the Department of Physical Culture } \\
\text { and Fundamentals of Health, Yuriy Fedkovych } \\
\text { Chernivtsi National University (Chernivtsi, } \\
\text { Ukraine) }\end{array}$ \\
\hline
\end{tabular}

УДК 796: 771.214

doi: 10.15330/fcult.36.9-16

Вімалій Кашуба, Сергій Холодов

\title{
БІОМЕХАНІЧНІ АСПЕКТИ ХОДЬБИ ДІТЕЙ МОЛОДШОГО ШКІЛЬНОГО ВІКУ
}

Мета. Визначити особливості часової структури ходьби практично здорових дітей 6-8 років. Методи. Для виконання поставлених завдань використано такі методи дослідження, як аналіз науковометодичної літератури та документальних матеріалів, відеометрія, пакет прикладної програми “БіоВідео”. Результати. Ходьба є ичилічним локомоторним рухом, здійснюваним за способом відштовхування. Характерною особливістю ходьби є наявність постійного контакту опорної ноги (період одиночної опори) або обох ніг (період подвійної опори). Саме ходьба може служити в якості критерію оцінки стану моторики людини. У той же час, накопичені більш ніж за столітній період дані, щзо стосуються питань фазового складу ходьби, ролі і иільової спрямованості кожної з фаз в ичилі подвійного кроку, механізму реалізації основних рухових дій, принципово один від одного не відрізняються. При цьому інформація про формування біомеханіки ходьби у молодших школярів обмежена. Проведені дослідження свідчать про те, щуо тривалість фази подвійної опори при лівій опорній нозі у практично здорових хлопчів 6 років дорівнюе в середньому $0,12 c(S=0,01 c), y$ дівчат $-0,14 c(S=0,01 c)$, водночас $y$ практично здорових хлопиів і дівчат 7 років показники тривалості иієї фази однакові і складають 0,14 $\mathrm{c}$ $(S=0,01$ c), так само однакова тривалість иүієї фази у хлопців і дівчат 8 років і становить $0,16 c(S=0,02$ с y хлопців $i S=0,01$ с у дівчат). Необхідно відмітити, щуо статистично значущеї різниці у показнику тривалості фази подвійної опори при лівій опорній нозі між хлопиями та дівчатами у кожній з вікових категорій 7-8 років не спостерігалоя (р > 0,05) на відміну від хлопців і дівчат 6 років, у яких показники тривалості иієї фази статистично значуще відрізнялися ( $p<0,05)$, щуо підтверджено за допомогою критерію Стьюдента для незалежних вибірок. Варто відмітити, щуо у заключній фазі подвійного кроку ходьби, зафіксовано статистично значуще збільшення ї тривалості у дівчат 7 років, порівняно з хлопиями иъього віку на 0,04 c (p < 0,05), ї̈ тривалість становить у дівчат 7 років, а також у хлопиів і дівчат 8 років в середньому 0,24 с $(S=0,03$ с у дівчат 7 років і хлопців 8 років $i \mathrm{~S}=0,02$ с у дівчат 8 років). Висновок. В результаті проведеного дослідження була вивчена структура циику ходьби практично здорових дітей 6-8 років, значимість яких підтверджена об'єктивними часовими показниками. Підтверджено думку ряду фахівиів, які вказують, щъо біомеханічна структура локомоторного акту практично повністю складається у віиі 7-8 років.

Ключові слова: діти молодшого шкільного віку, статодинамічна постава, часова структура ходьби, біомеханічні аспекти. 
Aim. Identify the features of walking temporal structure of almost healthy children aged 6-8 years. Methods. To perform the tasks, there were used such research methods as scientific and methodological literature and documentary materials analysis, videometry, "BioVideo" application package. Results. Walking is a cyclic locomotor movement using the repulsion moves. A characteristic feature of walking is a constant supporting leg contact (single support period) or both legs contact (double support period). Walking can serve as a criterion of human motility state assessing. At the same time, the data accumulated over a centuries, according to walking phase composition, the role and purpose of each of the phases in double step cycle, the mechanism of main motor actions implementation, do not differ. Herewith, information on the formation of walking biomechanics in younger schoolers is limited. Conducted studies show that the duration of double support phase with left supporting leg in almost healthy boys aged 6 years is on average $0.12 s(S=0.01 s)$, in girls $-0.14 \mathrm{~s}(S=0.01 \mathrm{c})$, at the same time in almost healthy 7 year-old boys and girls this phase duration indicators are the same and are $0.14 \mathrm{~s}(\mathrm{~S}=0.01 \mathrm{~s})$, as well as in 8 year-old boys and girls and are $0.16 \mathrm{~s}$ $(S=0.02 \mathrm{~s}$ in boys and $S=0.01 \mathrm{~s}$ in girls). It should be noted that a statistically significant difference in double support phase duration with left supporting leg between boys and girls in each 7-8 year-old categories was not observed ( $p>0.05)$ in contrast to 6 year-old boys and girls, where indicators of this phase duration differed statistically significantly ( $p<0.05)$, that was confirmed by Student's criterion for independent samples. It also should be noted that in the final phase of double walking step, there was a statistically significant duration increase in 7 year-old girls, compared with boys of the same age by $0.04 s$ ( $p$ <0.05), its duration in 7 year-old girls, and in 8year-old boys and girls is on average $0.24 \mathrm{~s}(\mathrm{~S}=0.03 \mathrm{~s}$ in 7 year-old girls and 8year-old boys and $S=0.02 \mathrm{~s}$ in 8 year-old girls ). Conclusion. As a result of the study, the walking cycle structure in almost healthy 6-8 year-old children was studied, which significance was confirmed by objective time indicators. A number of experts confirm the opinion that biomechanical locomotor act structure is almost completely formed at the age of 7-8 years.

Keywords: children of primary school age, statodynamic posture, temporal walking structure, biomechanical aspects.

Постановка проблеми й аналіз результатів останніх досліджень. Ходьба людини носить циклічний характер і це означає, що, проаналізувавши один цикл, ми отримуємо інформацію, що характеризує всю локомоцію в цілому $[1,8,9]$. Характерною особливістю ходьби є наявність постійного контакту опорної ноги (період одиночної опори) або обох ніг (період подвійної опори) [1, 4]. У свою чергу періоди одиночної і подвійної опори поділяються на фази: задній крок, передній крок і фазу подвійної опори $[1,5,7]$.

Основний динамічний ефект при ходьбі - підйом і просування вперед загального центру мас тіла - створюється завдяки підсумовування силових ефектів, м'язів розгиначів обох ніг $[2,10,11]$. Хоча вирішальна роль при ходьбі належить рухам і роботі м'язів ніг, певні завдання цих локомоцій виконують і м'язи верхніх частин тіла. Так, нижня половина тулуба при ходьбі здійснює складний рух, яке може бути спроектована на три взаємно перпендикулярні площини $[1,2]$. Як відзначають багато дослідників [2, 14], саме ходьба може служити в якості критерію оцінки стану моторики людини.

Сьогодні існують десятки методів аналізу ходьби: методи реєстрації загальних, кінематичних, динамічних параметрів, пододинамометрія, акселерометрія тощо. До загальних відносять просторові і часові параметри ходьби $[6,13]$.

Мета дослідження - визначити особливості часової структури ходьби практично здорових дітей 6-8 років.

Методи дослідження. Для виконання поставлених завдань використано такі методи дослідження, як аналіз науково-методичної літератури та документальних матеріалів, відеометрія, пакет прикладної програми "БіоВідео". Програма "БіоВідео" дозволяє отримувати біомеханічні характеристики як окремих біоланок, так і всього тіла людини. Прикладне програмне забезпечення "БіоВідео" включає чотири модулі: 1) модуль конструювання моделей опорно-рухового апарату (ОРА) людини (як модель OPA використовувався 14-сегментний розгалужений біокінематичний ланцюг, координати ланок якого за геометричними характеристиками відповідають координатам 
положення у просторі біоланок тіла людини, а точки відліку - координатам центрів основних суглобів); модуль дозволяє створювати багатоланкові моделі ОРА, що містять до 100 точок відліку; 2) модуль визначення координат точок відносно соматичної системи відліку; 3) модуль розрахунку біомеханічних характеристик рухової дії за координатами моделі ОРА людини (програмні можливості модуля дозволяють розраховувати локалізацію центрів мас (ЦМ) біоланок і загального центра мас (ЗЦМ) тіла людини); 4) модуль побудови біокінематичної схеми тіла людини за відеограмою рухових дій з визначенням траєкторій руху центрів суглобів, ЦМ біоланок і ЗЦМ тіла людини [12].

Вивчення часових характеристик полягало у визначенні тривалості як подвійного кроку ходьби в цілому, так і її фаз зокрема (фази подвійної опори, заднього і переднього кроку), а також у встановленні ритмічної структури ходьби практично здорових дітей 6-8 років.

Результати досліджень. Встановлено, що тривалість фази подвійної опори при лівій опорній нозі у практично здорових хлопців 6-ти років дорівнює в середньому 0,12 с $(\mathrm{S}=0,01 \mathrm{c})$, у дівчат $-0,14 \mathrm{c}(\mathrm{S}=0,01 \mathrm{c})$, водночас у практично здорових хлопців і дівчат 7-ми років показники тривалості цієї фази однакові і складають 0,14 с (S = 0,01 c), так само однакова тривалість цієї фази у хлопців і дівчат 8 років і становить 0,16 с $(\mathrm{S}=0,02$ с у хлопців і $\mathrm{S}=0,01$ с у дівчат) (табл. 1$)$.

\section{Часова характеристика фаз ходьби практично здорових} дітей 6-8-ми років $(\mathrm{n}=600)$

\begin{tabular}{|c|c|c|c|c|c|c|}
\hline \multirow{3}{*}{ Назва фази } & \multirow{3}{*}{$\begin{array}{l}\text { Вік, } \\
\text { років }\end{array}$} & \multicolumn{4}{|c|}{ Тривалість фази, с } & \multirow{3}{*}{$\begin{array}{c}\text { Статист. } \\
\text { значущість } \\
\text { різниці між } \\
\text { хлопцями і } \\
\text { дівчатами, }\end{array}$} \\
\hline & & \multicolumn{2}{|c|}{ хлопці, n=300 } & \multicolumn{2}{|c|}{ дівчата, $n=300$} & \\
\hline & & $x$ & $\mathrm{~S}$ & $x$ & $\mathrm{~S}$ & \\
\hline \multirow{3}{*}{$\begin{array}{l}\text { Фаза подвійної опори } \\
\text { при лівій опорній нозі }\end{array}$} & 6 & 0,12 & 0,01 & 0,14 & 0,01 & $<0,05$ \\
\hline & 7 & 0,14 & 0,01 & 0,14 & 0,01 & $>0,05$ \\
\hline & 8 & 0,16 & 0,02 & 0,16 & 0,01 & $>0,05$ \\
\hline \multirow{3}{*}{$\begin{array}{l}\text { Фаза заднього кроку } \\
\text { при лівій опорній нозі }\end{array}$} & 6 & 0,16 & 0,01 & 0,16 & 0,01 & $>0,05$ \\
\hline & 7 & 0,16 & 0,02 & 0,18 & 0,02 & $<0,05$ \\
\hline & 8 & 0,18 & 0,02 & 0,20 & 0,02 & $<0,05$ \\
\hline \multirow{3}{*}{$\begin{array}{l}\text { Фаза переднього кроку } \\
\text { при лівій опорній нозі }\end{array}$} & 6 & 0,20 & 0,02 & 0,22 & 0,02 & $<0,05$ \\
\hline & 7 & 0,20 & 0,02 & 0,24 & 0,02 & $<0,05$ \\
\hline & 8 & 0,24 & 0,02 & 0,28 & 0,03 & $<0,05$ \\
\hline \multirow{3}{*}{$\begin{array}{l}\text { Фаза подвійної опори } \\
\text { при правій опорній } \\
\text { нозі }\end{array}$} & 6 & 0,12 & 0,01 & 0,10 & 0,01 & $<0,05$ \\
\hline & 7 & 0,12 & 0,01 & 0,14 & 0,01 & $<0,05$ \\
\hline & 8 & 0,14 & 0,02 & 0,16 & 0,02 & $<0,05$ \\
\hline \multirow{3}{*}{$\begin{array}{l}\text { Фаза заднього кроку } \\
\text { при правій опорній } \\
\text { нозі }\end{array}$} & 6 & 0,20 & 0,03 & 0,20 & 0,02 & $>0,05$ \\
\hline & 7 & 0,18 & 0,02 & 0,16 & 0,02 & $<0,05$ \\
\hline & 8 & 0,16 & 0,02 & 0,16 & 0,01 & $>0,05$ \\
\hline \multirow{3}{*}{$\begin{array}{l}\text { Фаза переднього кроку } \\
\text { при правій опорній } \\
\text { нозі }\end{array}$} & 6 & 0,20 & 0,02 & 0,20 & 0,03 & $>0,05$ \\
\hline & 7 & 0,20 & 0,03 & 0,24 & 0,03 & $<0,05$ \\
\hline & 8 & 0,24 & 0,03 & 0,24 & 0,02 & $>0,05$ \\
\hline
\end{tabular}

Статистично значущої різниці у показнику тривалості фази подвійної опори при лівій опорній нозі між хлопцями та дівчатами у кожній з вікових категорій (7-8 років) не спостерігається ( $>$ > 0,05) на відміну від хлопців і дівчат 6-ти років, у яких показники 
тривалості цієї фази статистично значуще відрізняються $(\mathrm{p}<0,05)$, що підтверджено за допомогою критерію Стьюдента для незалежних вибірок.

Водночас ми не виявили статистично значущих відмінностей у часовій структурі фази заднього кроку при лівій опорній нозі між хлопцями і дівчатами 6-ти років ( $\mathrm{p}>0,05)$, тривалість якої склала $0,16 \mathrm{c}(\mathrm{S}=0,01 \mathrm{c})$, проте між показниками тривалості цієї фази у хлопців і дівчат 7-8-ми років спостерігається статистично значуща різниця $(\mathrm{p}<0,05)-0,16 \mathrm{c}(\mathrm{S}=0,02 \mathrm{c})$ у хлопців 7-ми років, у дівчат цього ж віку і хлопців 8 років $-0,18 \mathrm{c}(\mathrm{S}=0,02 \mathrm{c})$, у дівчат 8 років $-0,20 \mathrm{c}(\mathrm{S}=0,02 \mathrm{c})$.

Тривалість фази переднього кроку при лівій опорній нозі у хлопців і дівчат усіх вікових категорій (6-8 років) статистично значуще відрізняється ( $<<0,05)$ - у практично здорових хлопців 6-7-ми років вона дорівнює $0,20 \mathrm{c}(\mathrm{S}=0,02 \mathrm{c})$, хлопців 8-ми років $-0,24 \mathrm{c}(\mathrm{S}=0,02 \mathrm{c})$, дівчат 7-ми років $-0,24 \mathrm{c}(\mathrm{S}=0,02 \mathrm{c})$ і дівчат 8-ми років відповідно 0,28 с $(\mathrm{S}=0,03 \mathrm{c})$. У фазі переднього кроку опорної ноги поздовжня вісь винесеної вперед ноги перебуває спереду від вертикалі, опущеної з ЗЦМ тіла [3]. Сила тяжіння спрямована вниз, строго перпендикулярно до опорної поверхні, а сила реакції опори має косий напрямок, відповідно поздовжньої осі опорної ноги. Якщо силу реакції опори розкласти на складові - вертикальну і горизонтальну, то горизонтальна складова буде направлена назад, що, природно, декілька загальмовує поступальний рух тіла [3].

Розглядаючи часову структуру фази подвійної опори при правій опорній нозі, слід зазначити, що ії тривалість статистично значуще більша у хлопців, ніж у дівчат 6ти років, і статистично значуще менша у хлопців, ніж у дівчат 7-8-ми років $(\mathrm{p}<0,05)$.

Водночас у практично здорових хлопців 7-ми років фаза заднього кроку при правій опорній нозі триваліша в середньому на 0,02 с порівняно з дівчатами цього віку $(\mathrm{p}<0,05)$. При цьому у хлопців 7-ми років вона склала $0,18 \mathrm{c}(\mathrm{S}=0,02 \mathrm{c})$, а у дівчат 0,16 с $(\mathrm{S}=0,02 \mathrm{c})$. Водночас, немає статистично значущої різниці між практично здоровими хлопчиками і дівчатами як у віці 6 , так і 8 років $(\mathrm{p}>0,05)$.

Фаза заднього кроку $є$ найбільш важливою, так як в кінці її за рахунок скорочення м'язів нижніх кінцівки відбувається поштовх, що надає додатковий імпульс, необхідний для поступального руху вперед [3]. У період заднього кроку опорної ноги закінчується перекочування стопи, опора 3 усією підошви переходить на фаланги падьців. Площа опори різко зменшується. Дія сили тяжіння направлена перпендикулярно вниз, а сили реакції опори - вгору, вздовж осі опорної ноги. У міру переміщення вільної ноги вперед, яке відбувається синхронно із заднім кроком опорної ноги, ЗЦМ тіла зміщується вперед [3]. В результаті цього виникає плече сили тяжіння. Коли момент сили тяжіння стає більшим за момент сили реакції опори, рівновага тіла порушується, і воно під дією сила тяжіння опускається на виставлену вперед вільну ногу. Горизонтальна складова рівнодіючої сили реакції опори сприяє поступальному руху, збільшуючи швидкість переміщення тіла [3].

У заключній фазі подвійного кроку ходьби, знову відзначено статистично значуще збільшення іiї тривалості у дівчат 7-ми років, порівняно з хлопцями цього віку на $0,04 \mathrm{c}(\mathrm{p}<0,05)$, iї тривалість становить у дівчат 7-ми років, а також у хлопців і дівчат 8 -ми років в середньому 0,24 с $(\mathrm{S}=0,03$ с у дівчат 7 -ми років і хлопців 8 -ми років $\mathrm{i}$ $\mathrm{S}=0,02$ с у дівчат 8 -ми років).

На рис. 1-3 представлено лінійні хронограми ходьби практично здорових дітей 6-8 років.

Дискусія. Вивчення питань, пов'язаних із організацією руху дитини, - одне 3 найважливіших завдань теорії i методики фізичного виховання і диференціальної біомеханіки. У даному дослідженні вивчалися різні аспекти біомеханіки ходьби дітей 6-8 років. Результати досліджень кінематики ходьби дітей молодшого шкільного віку 
підтверджують дані М.О. Бернштейна (1940), А.М. Лапутіна, (2000) та інших, які вказують на те, що кінцеве формування “дорослої” біомеханічної структури ходьби у віці 7-8 років.

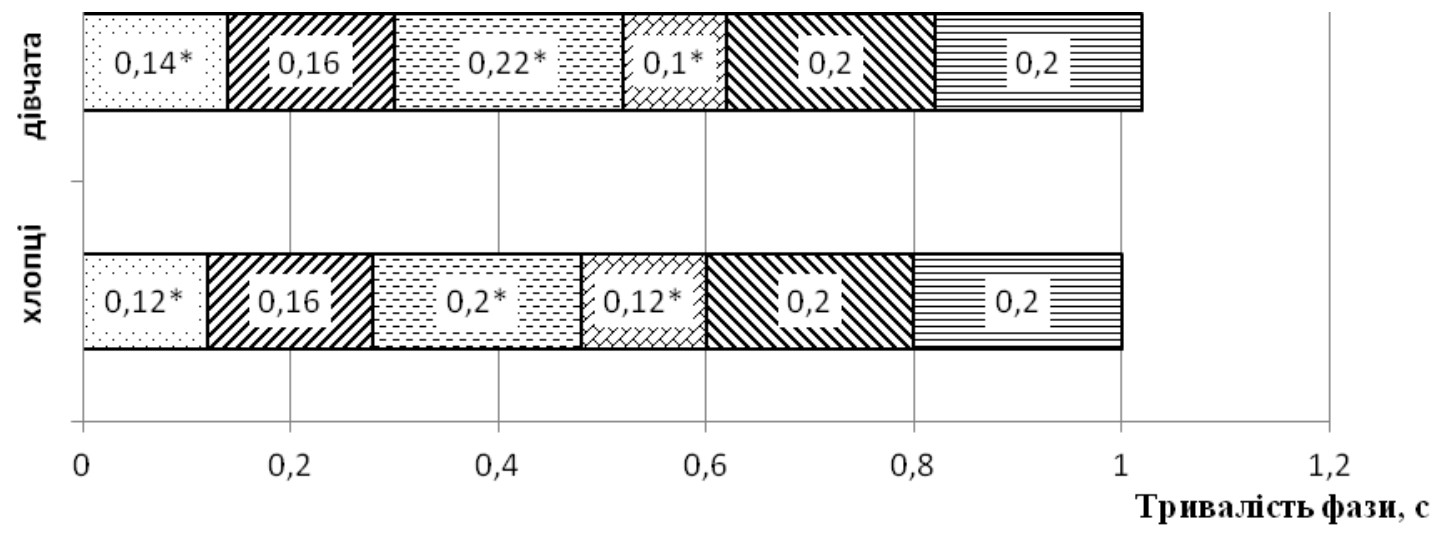

Рис. 1. Лінійна хронограма тривалості фаз ходьби практично здорових дітей 6-ти років (* - різнщя статистично значуща між показникамп хлопщів і дівчат на рівні $\mathrm{p}<0,05)$ :

$\square$ Фаза подвійної опори при лівій опорній нозі $\boldsymbol{\square}$ Фаза заднього кроку при лівій опорній нозі 曰Фаза переднього кроку при лівій опорній нозі 曰 Фаза подвійної опори при правій опорній нозі

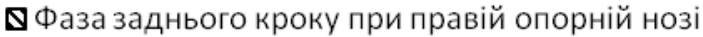
目Фаза переднього кроку при правій опорній нозі

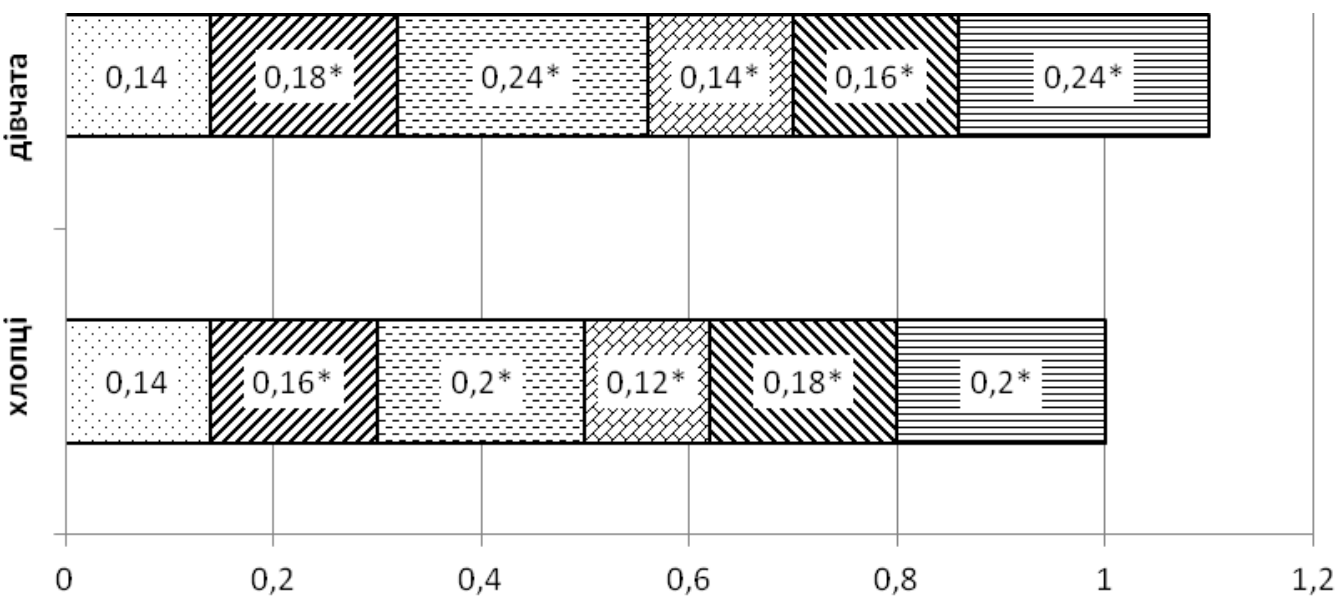

Pис. 2 Лінійна хронограма тривалості фаз ходь би практично

Тривалість фази, с здорових дітей 7-мп років ( ${ }^{*}$ - різншщя статистично значуща між показникамп хлопщів і дівчат на рівні $\mathrm{p}<0,05)$ :

\footnotetext{
๑аза подвійної опори при лівій опорній нозі

$\boldsymbol{\square}$ Фаза заднього кроку при лівій опорній нозі

曰Фаза переднього кроку при лівій опорній нозі

曰Фаза подвійної опори при правій опорній нозі

$\boldsymbol{\Delta}$ Фаза заднього кроку при правій опорній нозі

目Фаза переднього кроку при правій опорній нозі
} 


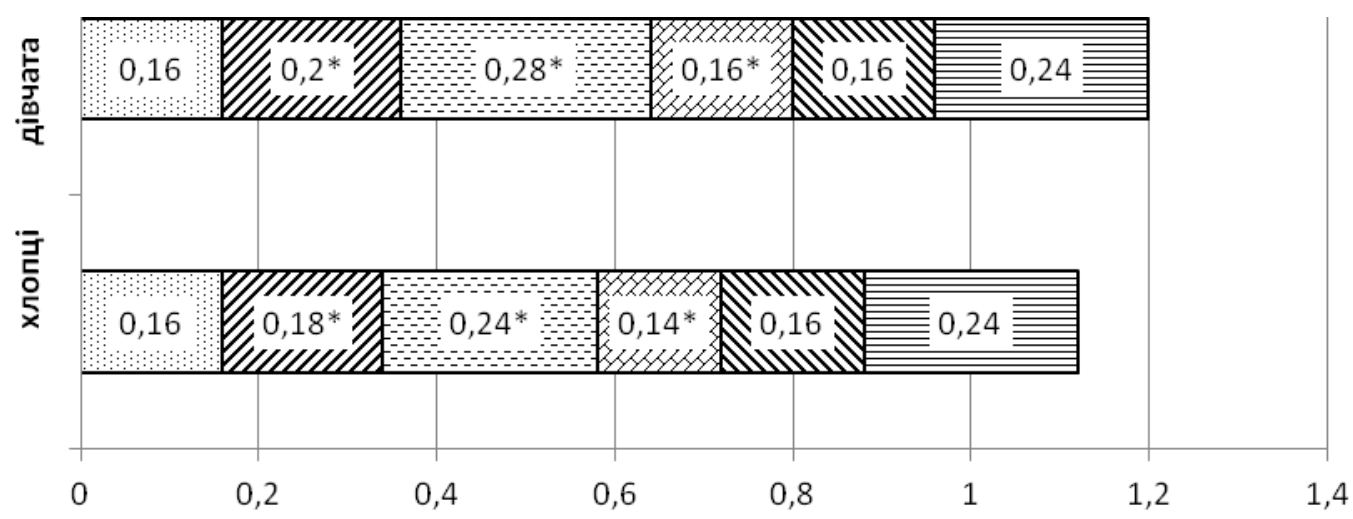

Рис. 3. Лінійна хронограма тривалості фаз ходьби практично Тривалість фази, с здорових дітей 8 -мп років (* - різнщя статистично значуща між показнгкамп хлопщів і дівчат на рівні $\mathrm{p}<0,05$ )

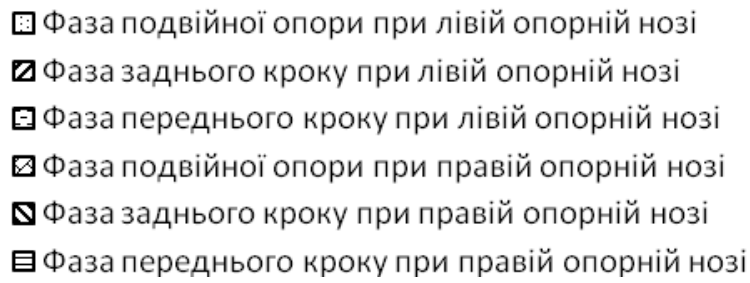

Ми підтримуємо думки фахівців А.С. Витензон, (1998), S.Savlyuk, (2017) які відзначають, що оскільки величина навантаження на нижні кінцівки при локомоціях значною мірою залежить від просторового розташування усіх відділів ОРА людини, що знаходяться вище, необхідно фізичні вправи спрямовувати на формування навички правильної статодинамічної постави, що забезпечує нормальне функціонування опорно-ресорного апарату нижніх кінцівок і всього ОРА.

Висновок. Вивчення біомеханіки пересування людини дає великий матеріал для розуміння фізіологічних і нервових процесів, що визначають функціонування системи управління локомоціями. В результаті проведеного дослідження була вивчена структура циклу ходьби практично здорових дітей 6-8 років, значимість яких підтверджена об'єктивними часовими показниками. Підтверджено думку ряду фахівців, які вказують, що біомеханічна структура локомоторного акту практично повністю формується у віці 7-8 років.

1. Бернштейн НА, Осипов ЛС, Павленко ПИ. Исследование по биодинамике ходьбы, бега, прыжка. М.: Медицина, $1940.320 \mathrm{c}$.

2. Витензон АС. Закономерности нормальной и патологической ходьбы человека. М.: ООО “Зеркало-М”, $1998.273 \mathrm{c}$.

3. Кашуба В, Андрєєва К, Сергієнко Н. Гончарова. Проектування системи моніторингу фізичного стану школярів на основі використання інформаційних технологій. Теорія і методика фізичного. виховання і спорту. 2006; 3: 61-67.

4. Кашуба ВА, Адель Бен Жедду, Хабинец ТА. Кинематический анализ естественной локомоции младших школьников с нарушениями морфо-биомеханических свойств стопы. Молода спортивна наука України. 2006; 10: 32-35.

5. Кашуба ВА, Литвиненко ЮВ, Гордеева МВ, Зарудный ВЮ. Биомеханика спортивных движений и современные видеокомпьютерные методы их контроля Теория и методика физической культуры. 2013; 4 (35): 31-37.

6. Кашуба В, Хабинец Т, Лопацкий С. Гнатыш Г. Статодинамическая осанка - индакатор двигательной функции человека Молодіжний науковий вісник Східноєвропейського національного уні- 
верситету імені Лесі Українки. Фізичне виховання і спорт: журнал / уклад. А. В. Цьось, А. І. Альошина. Луцьк : Східноєвроп. нац. ун-т ім. Лесі Українки. 2018; 29: 9-14.

7. Кашуба В, Гончарова Н. Досвід упровадження концепції здоров'яформувальних технологій у процес фізичного виховання дітей молодшого шкільного віку Молодіжний науковий вісник Східноєвропейського національного університету імені Лесі Українки. Фізичне виховання і спорт : журнал / уклад. А. В. Цьось, А. І. Альошина. Луцьк : Східноєвроп. нац. ун-т ім. Лесі Українки. 2018; 9: 63-70.

8. Лапутин АН, Кашуба ВА. Формирование массы и гравитационные взаимодействия тела человека в процессе онтогенеза: Знания Украины, 1999. 198 с.

9. Лапутін АМ, Кашуба ВО. Динамічна анатомія: Навчальна програма для вузів фізичного виховання та спорту. Київ, Науковийсвіт, 2000. 12 с.

10. Лапутін АМ, Кашуба ВО. Хабінець ТО. Кінетика як система знань про рухову функцію людини. Теорія і методика фізичного виховання і спорту. К.: 2005; 2-3: 96-101.

11. Лапутин АН, Кашуба ВА. Кинетика тела человека. Фізичне виховання, спорт і культура здоров'я у сучасному суспільстві. 2009; 4: 40-49.

12. Лапутин АН, Гамалий ВВ, Архипов АА, Кашуба ВА, Носко НА, Хабинец ТА. Практическая биомеханика. К.: Знання, 2000. 296 с.

13. Kashuba V, Khmelnitska I. Computer system for monitoring of hard hearing school-child's motorics Теорія і методика фізичного виховання і спорту. 2014; 3: 50-53.

14. Kashuba V, Savlyuk S. Structure and content of the technology of prevention and correction of disturbances of spatial organization of the body of children 6-10 years old with sensory systems deprivation Journal of Education, Health and Sport. 2017. 7(8): 1387-1407.

15. Kashuba V, Futornyi S, Andrieieva O, Goncharova N, Carp I, Bondar O, Nosova N. Optimization of the processes of adaptation to the conditions of study at school as a component of health forming activities of primary school-age children Journal of Physical Education and Sport (JPES), 18(4), 2018; 377: 2515-2521.

\section{References}

1. Bernstein NA, Osipov LS, Pavlenko PI. Research on the biodynamics of walking, running, jumping. M .: Meditsina, 1940. $320 \mathrm{~s}$.

2. Wittenson AC. Regularities of normal and pathological human walking. M.: OOO “Zerkalo-M", 1998. 273 p.

3. Kashuba V, Andreeva K, Sergienko N. Goncharova. Designing a system for monitoring the physical condition of students based on the use of information technology Theory and methods of phys. education and sports. 2006; 3: 61-67.

4. Kashuba VA, Adele Ben Jeddu, Habinets TA. Kinematic analysis of natural locomotion of junior schoolchildren with disorders of morphobiomechanical properties of the foot // Young Sports Science of Ukraine. 2006; 10: 32-35.

5. Kashuba VA, Litvinenko SE, Gordeeva CF, Zarudny VU. Biomechanics of sports movements and modern video computer methods of their control Theory and methods of physical culture. 2013; 4 (35): 31-37.

6. Kashuba V, Khabinets T, Lopatsky S. Hnatysh G. Statodynamic posture - an indicator of human motor function Youth Scientific Bulletin of the East European National University named after Lesya Ukrainka. Physical education and sports: magazine / style. AV Tsyos, AI Alyoshin. Lutsk: Eastern Europe. nat. Univ. Lesya Ukrainka, 2018; 29: 9-14.

7. Kashuba V, Goncharova N. Experience of introduction of the concept of health-forming technologies in the process of physical education of children of primary school age Youth Scientific Bulletin of the Lesya Ukrainka East European National University. Physical education and sports: magazine / style. AV Tsyos, AI Alyoshin. Lutsk: Eastern Europe. nat. Univ. Lesya Ukrainka, 2018; 29: 63-70.

8. Laputin AN, Kashuba VA. Mass formation and gravitational interactions of the human body in the process of ontogenesis: Knowledge of Ukraine, 1999. 198 p.

9. Laputin AM, Kashuba VO. Dynamic Anatomy: Curriculum for Physical Education and Sports. Kyiv, Naukovysvit, 2000. 12 p.

10. Laputin AM, Kashuba VO. Habinets THAT. Kinetics as a system of knowledge about human motor function. Theory and methods of physical education and sports. 2005; 2-3: 96-101.

11. Laputin AN, Kashuba VA. Kinetics of the human body. Physical education, sports and health culture in modern society. 2009; 4: 40-9.

12. Laputin AN, Gamaliy BB, Arkhipov AA, Kashuba VA, Nosko NA, Habinets TA. Practical biomechanics. K $\therefore$ Knowledge, 2000. 296 p.

13. Kashuba V, Khmelnitska I. Computer system for monitoring of hard hearing school-child's motorics Теорія і методика фізичного виховання і спорту. 2014; 3: 50-53.

14. Kashuba V, Savlyuk S. Structure and content of the technology of prevention and correction of disturbances of spatial organization of the body of children 6-10 years old with sensory systems deprivation Journal of Education, Health and Sport. 2017; 7(8): 1387-1407. 
15. Kashuba V, Futornyi S, Andrieieva O, Goncharova N, Carp I, Bondar O, Nosova N. Optimization of the processes of adaptation to the conditions of study at school as a component of health forming activities of primary school-age children Journal of Physical Education and Sport (JPES) 201818(4); 377: 2515-2521.

Цитування на цю статтю:

Кашуба ВА, Холодов СА. Біомеханічні аспекти ходьби дітей молодшого шкільного віку. Вісник Прикарпатського університету. Серія: Фізична культура. 2020 Листоп 24; 36: 9-16

\begin{tabular}{|c|c|}
\hline Відомості про автора: & Information about the author: \\
\hline $\begin{array}{l}\text { Кашуба Віталій Олександрович - доктор наук } 3 \\
\text { фізичного виховання та спорту, професор, Націо- } \\
\text { нальний університет фізичного виховання і спорту } \\
\text { України (Київ, Україна) }\end{array}$ & $\begin{array}{l}\text { Kashuba Vitaliy Oleksandrovych-Doctor of Science } \\
\text { of Physical Education and Sport, Professor, National } \\
\text { University of Ukraine on Physical Education and Sport } \\
\text { (Kyiv, Ukraina) }\end{array}$ \\
\hline \multicolumn{2}{|l|}{$\begin{array}{l}\text { e-mail: Vitaliy_kashuba@ukr.net } \\
\text { https://orcid.org/0000-0001-6669-738X }\end{array}$} \\
\hline $\begin{array}{l}\text { Холодов Сердій Анатолійович - кандидат педаго- } \\
\text { гічних наук, доцент, доцент кафедри біології і ос- } \\
\text { нов здоров'я, ДЗ “Південноукраїнський національ- } \\
\text { ний педагогічний університет імені К. Д. Ушин- } \\
\text { ського” (Одеса, Україна) }\end{array}$ & $\begin{array}{l}\text { Kholodov Serhii Anatoliyovych-Candidate Degree in } \\
\text { Pedagogy, Associate professor, Department of Biology } \\
\text { and Heals Fundamentals, State Institution "South } \\
\text { Ukrainian National Pedagogical University named } \\
\text { after K.D. Ushynsky" (Odesa.Ukraina) }\end{array}$ \\
\hline
\end{tabular}
УДК 796: 616.314 Віталій Кашуба, Георгій Ярош, Юрій Крикун, Тамара Хабінець,
doi: 10.15330/fcult.36.16-25 Наталія Домашенко, Андрій Шанковський

\title{
СТАН ПРОСТОРОВОЇ ОРГАНІЗАЦІЇ ТІЛА ЮНИХ СПОРТСМЕНІВ ЯК ПЕРЕДУМОВА РОЗРОБЛЕННЯ Й УПРОВАДЖЕННЯ КОРЕКЦЙ̆НО-ПРОФІЛАКТИЧНИХ ЗАХОДІВ У ТРЕНУВАЛЬНИЙ ПРОЦЕС
}

\begin{abstract}
Мета. Узагальнення теоретичних знань, вітчизняного та зарубіжного досвіду в галузі використання технологій зберігання та коригування здоров'я у процесі підготовки юних спортсменів, а також у визначенні перспектив їхнього застосування за сучасних умов. Методи. Аналіз і систематизація даних науково-методичної літератури, інформаційних ресурсів мережі Інтернет. Результати. На сучасному етапі методика спортивної підготовки позначена втіленням низки радикальних змін, спричинених посиленою конкуренцією на найбільш визнаних у світі змаганнях і актуалізацією тренувальних програм, виконання яких здебільшого вимагає перевищення адаптаџійного потенціалу людського організму. Найбільш нагальною щзоо розв'язання означена проблема постає на початкових етапах багаторічної підготовки дітей і підлітків, специфіку яких складає інтенсивне витрачання резервів їхнього організму на природний ріст і розвиток. Перспективи подальших досліджень убачаємо передусім у розробленні технології профілактики та корекиії порушень просторової організації тіла юних спортсменів. Тому навчально-тренувальні заняття таких спортсменів набудуть не тільки спортивно-результативної, а й оздоровчої спрямованості за умов: урахування під час програмування та конкретного планування засобів спортивного тренування індивідуальних характеристик просторової організації тіла юних спортсменів, рівня їхньої фізичної підготовленості та послідовності виконання ними завдань фізичного вдосконалення. Висновок. Виконання тренувальних навантажень, які перевищують адаптаційний потенціал організму підлітків, інтенсивне витрачання резервів їхнього організму на природний ріст і розвиток й диференціацію фізіологічних систем висуває цілу низку проблем щуодо збереження їх здоров'я. Складність вирішення иієё проблеми посилюють такі фактори, як: рання спеціалізаџія в спорті та негативний вплив на організм щзоденних тренувань з граничними (піковими) фізичними навантаженнями. Відтак, виникають суперечності між підвищеними вимогами до підготовленості юних спортсменів, пов'язаними з потребою систематичного зростання результатів, і обмеженими функціональними можливостями їхнього організму на ранньому етапі онтогенезу.
\end{abstract}

Ключові слова: порушення просторової організації тіла, юні спортсмени, корекційно-профілактичні заходи. 